\begin{tabular}{|c|c|c|c|}
\hline & $\begin{array}{l}\text { Escola Superior } \\
\text { de Cétstóe } \\
\text { Tecrologia } \\
\text { [ipsantarém }]\end{array}$ & 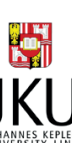 & $\begin{array}{l}\text { ISSN 2029-7564 (online) } \\
\text { SOCIALINÉS TECHNOLOGIJOS } \\
\text { SOCIAL TECHNOLOGIES } \\
2013,3(1) \text {, p. } 39-52\end{array}$ \\
\hline
\end{tabular}

\title{
SOCIALINIO MARKETINGO TECHNOLOGIJŲ TAIKYMO GALIMYBE்S ELEKTRONINĖS VALDŽIOS PASLAUGŲ VIEŠINIMUI
}

\author{
Tadas Limba \\ Mykolo Romerio universitetas, Lietuva, tlimba@mruni.eu \\ Konstantin Agafonov \\ Mykolo Romerio universitetas, Lietuva,ka1979@gmail.com \\ doi:10.13165/ST-13-3-1-03
}

\section{Santrauka}

Tikslas - išanalizuoti veiksnius, turëjusius įtakos socialiniam marketingui atsirasti, tradicinio ir socialinio marketingo sąlyčio taškus bei pateikti naudingas rekomendacijas dèl socialinio marketingo kampanijos parengimo ir vykdymo, siekiant viešinti ir tobulinti elektroninès valdžios paslaugu projektus.

Metodologija - nagrinëjant anksčiau nurodytus veiksnius, skatinančius socialinio marketingo atsiradima, socialinio marketingo naudojimo ypatybes ir tikslus, taikyti sistemines analizès bei koncepcinès lyginamosios analizès metodai leidžia geriau atskleisti socialinio marketingo taikymo ypatybes bei pateikti socialinio marketingo kampanijos organizavimo modeli.

Rezultatai - atskleistas socialinio marketingo evoliucijos procesas, pateiktas socialinio marketingo panaudojimo ir marketingo kampanijos parengimo teorinis modelis, kuris pades itraukti daugiau suinteresuotu visuomenès grupiu, diegiant naujas bei plètojant jau esamas elektronines valdžios teikiamas paslaugas, taip pat pagelbès organizacijoms, atsakingoms už elektroninès valdžios paslaugu kürima ir viešinima, lengviau igyvendinti ir plètoti ju kuruojamus projektus. 
Praktinè reikšmè - atlikus socialinio marketingo technologiju taikymo analizę, išryškejo tam tikri probleminiai klausimai, todèl ju sprendimo büdai leistu efektyviau igyvendinti socialinio marketingo technologijas įvairiu šaliu valstybès valdymo įstaigose ju vykdomu projektu taikymo kontekste.

Originalumas - darbo originaluma straipsnyje atspindi sudarytas dvipakopis socialinio marketingo technologiju ir priemoniu taikymo teorinis modelis, kuris iš esmes pateikia bendrus reikalavimus, reikalingus socialinio marketingo kampanijai parengti, taikyti ir toliau pletoti.

Raktažodžiai-socialinis marketingas, socialinio marketingo technologijos, marketingo kampanija, socialinio marketingo procesas, elektronine valdžia, elektroninès valdžios paslaugos.

Tyrimo tipas - socialinio marketingo technologiju ir elektroniniu viešuju paslangu marketingo kampanijos konstravimo ir vykdymo pristatymas.

\section{Ivadas}

Socialinis marketingas šiuolaikiniame pasaulyje yra tapęs vienu labiausiai paplitusiu procesu. Tai labai galingas įrankis, kurio naudojimas socialiniams projektams viešinti, socialiniams tikslams pasiekti tapo šiuolaikinio pasaulio kasdienybe. Iš esmės šios tradicinio marketingo atmainos atsiradimą ir aktyvų naudojimą šiuolaikiniame pasaulyje paskatino „technologinè revoliucija“, pasaulinio interneto tinklo atsiradimas ir ne pelno siekiančių organizacijų veiklos suaktyvèjimas, užtikrinant tam tikrų socialinių procesų ir projektų valdymą.

Nors socialinio marketingo procesas ir yra tapęs mūsų kasdienio gyvenimo dalimi ir naudojamas daugelyje socialiniu projektų, iki šiol nèra aiškios ir apibrèžtos socialinio marketingo naudojimo koncepcijos, kurią galima būtų panaudoti kuriant marketingo kampanijas elektroninès valdžios paslaugoms viešinti. Puikiai suprantama, kad socialinis marketingas yra labai panašus ị tradicinị marketingą, bet tuo pačiu metu šios dvi mokslo šakos turi ir savo naudojimo ypatumų.

Tyrimo objektas - socialinio marketingo technologijų panaudojimas diegiant ir viešinant elektroninès valdžios paslaugų projektus.

Tyrimo tikslas - išanalizuoti socialinio marketingo atsiradimą paskatinusius veiksnius, sudaryti bei pateikti socialinio marketingo kampanijos konstravimo teorinị modelị, kuris gali būti naudojamas kuriant ir tobulinant elektroninès valdžios projektus.

\section{Tyrimo uždaviniai:}

1. Atskleisti socialinio marketingo susiformavimo užuomazgas ir ypatumus;

2. Išnagrinèti socialinio marketingo atsiradimo priežastis;

3. Išanalizuoti socialinio marketingo kampanijos modelio konstravimo ypatumus elektroninių viešujų paslaugų projektų viešinimui. 
Darbo naujumą straipsnyje atspindi atlikta socialinio marketingo atsiradimą ir plètrą lèmusių veiksnių analizè, ịvairių pasaulio mokslininkų pateiktos nuomonès apie socialinio marketingo pritaikymo sritis bei pamąstymai, kaip socialinis marketingas gali paveikti ịprastą visuomenès elgesio modelį. Taip pat mokslinio straipsnio naujumą atspindi pateiktas socialinio marketingo kampanijos dvipakopis teorinis modelis, kuris gali būti naudojamas socialinio marketingo kampanijoms vykdyti.

\section{Socialinis marketingas - kas tai?}

Socialinis marketingas - tai rinkodaros rūšis, kurios atsiradimas yra siejamas su dvidešimtojo amžiaus aštuntuoju dešimtmečiu, kai mokslininkai Kotleris ir Zaltmanas suprato, kad rinkodaros technologijos, kurios yra naudojamos produktams ir paslaugoms populiarinti, taip pat sèkmingai gali būti panaudotos socialiniams projektams ir idèjoms vystyti.

Kotleris ir Zaltmanas yra laikomi socialinio marketingo pradininkais, bet pats socialinio marketingo atsiradimas yra siejamas su visuomeninèmis programomis, kurios buvo vykdomos ir populiarinamos Jungtinėse Amerikos Valstijose (JAV) šeštame dvidešimtojo amžiaus dešimtmetyje (Alves, 2012).

1952 metais G. D. Wiebe uždave klausimą: „Kodèl brolybė negali būti parduodama kaip muilas?" (Wiebe, 1951). Pasak Kotlerio ir Zaltmano (1971), G. D. Wiebe atliko tyrimus, kurių pagrindinis tikslas buvo išsiaiškinti, ar yra įmanoma tradicinius rinkodaros mechanizmus, kurie skatina muilo pardavimą, pritaikyti socialiniams projektams vystyti ir taip pat sèkmingai ,parduoti“ juos visuomenei (Kotler and Zaltman, 1971). G. D. Wiebe, vykdydamas savo tyrimus, suprato, kad kuo labiau socialinio projekto viešinimo kampanija panašèja ị produkto rinkodarą, tuo sékmingesnis ir patrauklesnis visuomenei būna šis socialinis projektas.

Iš esmès socialinio marketingo termino atsiradimą galima sieti su Kotlerio ir Levy (1969) pasiūlytu marketingo koncepcijos praplètimu, kuris teigè, kad „marketingas yra plačiai paplitusi visuomenès veikla, kuri daug svarbesnė už dantų pastos, muilo ir plieno pardavimus", ir su Kotlerio ir Zaltmano pateiktu socialinio marketingo apibrèžimu (Kotler and Levy, 1969; Kotler and Zaltman, 1971).

Pasak Kotlerio ir Zaltmano, socialinis marketingas yra „tradicinio marketingo atšaka, bet tai nėra tiesiog užbaigtas ir nekintantis marketingo priemonių modelis. Tai labiau - mokslo šakų rinkinys, kuriame susipynę psichologijos, sociologijos, antropologijos ir komunikacijos teorijos, padedančios suprasti, kaip galima paveikti žmonių pasirinkimą bei kokiu būdu pritaikyti tradicinès rinkodaros priemones socialiniams tikslams pasiekti““ (MacFadyen et al., 1999).

Kotleris is Zaltmanas teigè, kad socialinis marketingas, kaip ir tradicinis marketingas, yra paprastų veiksmų rinkinys, kuris yra grindžiamas logiško plano, susijusio su rinkos ir suinteresuotų grupių analize, rinkos segmentavimu, vartotojų nuomonès tyrimu, sudarymu, tačiau socialinis marketingas yra daug sunkiau igyvendinamas dalykas, nes siekia paveikti globalias sritis: socialinę politiką, ekonomiką, visuomenès elgesį. 
Tradicinio marketingo pagrindinis, aiškiai apčiuopiamas ir suprantamas tikslas yra pelno sukūrimas, materialinès gerovès didinimas. Socialinès rinkodaros esmė yra ne taip aiškiai apibrěžta ir suprantama, bet ji turi daug daugiau ambicijų: socialinio marketingo pagrindinis tikslas - užtikrinti ir pagerinti sunkiai išmatuojamą dalyką - visuomenès ar atskirų visuomenès grupių gyvenimo kokybę (MacFadyen et al.,1999).

Taigi, socialinis marketingas iš esmès yra tradicinio marketingo technologijų pritaikymas numatant, planuojant, rengiant bei igyvendinant visuomenines programas, kurios yra nukreiptos ị tos pačios visuomenès ar jos dalies gyvenimo kokybės ir/ar gerovès tobulinimą (Andreasen, 1993).

\section{Veiksniai, lèmę socialinio marketingo atsiradimą}

Socialinio marketingo plètra yra siejama su ne pelno siekiančių organizacijų atsiradimu bei jų vykdomų socialinių programų pagausėjimu pasaulyje. JAV šių organizacijų atstovai buvo labai suinteresuoti savo tikslinès auditorijos gausinimu, taip pat savo vykdomų projektų viešinimu, nes, kaip žinoma, didelè auditorija ir viešumas dažniausiai nulemia projekto sėkmę. Šiems tikslams pasiekti ne pelno siekiančių organizacijų atstovai dažnai kreipdavosi ị marketingo specialistus, kurie patardavo bažnyčioms, kaip pritraukti tikinčiuosius, aukojimo fondams - kaip surinkti piniginių lèšų vykdomiems projektams, o menų muziejams ir galerijoms - kaip rasti daugiau mecenatų.

Marketingo specialistai patardavo ne pelno siekiančių organizacijų atstovams, kaip organizuoti socialinio viešinimo kampanijas, kurios leisdavo šioms organizacijoms perteikti savo pagrindines socialines idèjas ir veiklos tikslus plačiajai visuomenei. Šios kampanijos buvo orientuotuos ị plačiają visuomenę ir leisdavo ne pelno siekiančioms organizacijoms tiksliai informuoti visuomenę apie vykdomus socialinius projektus sveikatos, socialinio gyvenimo, švietimo, nusikalstamumo mažinimo ir kitose srityse.

Socialinis viešinimas, kuris buvo viena iš mažiausiai ištirtų ir naudojamų komunikavimo technologijų socialinių projektų srityje, tapo pagrindiniu socialinio komunikavimo įrankiu. Pagaliau JAV socialinès komunikacijos naudojimo klausimas buvo pradètas vertinti ne kaip poreikis, o kaip būtinybė: klausimas „Ar būtina naudoti?“" transformavosi ị klausimą „Kaip naudoti ir kokie yra socialinio viešinimo naudojimo ypatumai bei taisyklès?" Socialinis viešinimas tapo labai populiarus, bet ne visos viešinimo kampanijos buvo sėkmingos, kadangi komunikavimo kampanijų vadovai socialini komunikavimą laikydavo pagrindiniu, o kartais ir vieninteliu aspektu, ị kurị buvo atkreipiamas dèmesys, siekiant ịgyvendinti socialinius projektus. Toks vienareikšmis požiūris ir rinkodaros principų nepaisymas labai dažnai nulemdavo socialinių projektų nesėkmes.

Socialinis marketingas, kaip teigė Kotleris ir Zaltmanas, yra platesnis reiškinys nei socialinis viešinimas ir yra apibrezžiamas kaip socialinėms programoms ir idèjoms viešinti panaudojamas projektavimo, igyvendinimo ir kontrolès priemonių rinkinys, kurio tikslas - didinti socialinių projektų priimtinumą visuomenèje, atsižvelgiant ị socialinio projekto planavimo, rinkodaros, komunikavimo ir palaikymo procesus. 
Pasak Kotleio ir Zaltmano, socialinis marketingas yra tradicinio marketingo priemonių ir technologijų praplètimas ị socialinę sferą; rinkinys priemonių, kurio tikslas yra konvertuoti šiuolaikinius socialinius poreikius ir iššūkius ị labiau suprantamas rinkodaros sudedamąsias dalis, kurios gali perteikti aiškesnius pasirinktų auditorijų išreiškiamus norus ir lūkesčius (Kotler and Zaltman, 1971).

Nors pirmasis socialinio marketingo apibrèžimas buvo pritaikytas socialinėms idèjoms ir iniciatyvoms vystyti, buvo sakoma, kad tai yra tas pats, tiesiog adaptuotas socialiniams projektams, tradicinis marketingas. Vèliau mokslininkai nusprendè, kad tos marketingo rūšys nėra visiškai tapačios. Po trijų dešimtmečių, praèjusių po pirmojo socialinio marketingo apibréžimo pateikimo mokslinei visuomenei, mokslininkai ir rinkodaros specialistai iš esmès sutarè, kad socialinis marketingas nèra skirtas tik idèjoms viešinti ir socialinėms programoms populiarinti. 2002 metais Kotleris, Roberto ir Lee socialinị marketingą ịvardino kaip ,,marketingo principų ir technologijų panaudojimą, siekiant paveikti tikslines auditorijas, kurios, paveiktos šios įtakos, savanoriškai keičia savo elgsenos principus“، (Kotler et al., 2002).

Kaip jau buvo minėta anksčiau, pagrindinis socialinio marketingo atsiradimą lèmęs dalykas buvo staigus ne pelno siekiančių organizacijų skaičiaus padidejjimas bei šių organizacijų vykdomos veiklos viešinimas ir populiarinimas, siekiant pritraukti investicijas, kurios buvo būtinos jų veiklai vykdyti.

Didžiausias ne pelno siekiančių organizacijų entuziazmas ir susidomėjimas socialinio marketingo technologijų panaudojimu savo veikloje buvo pastebètas, praejjus trisdešimt penkeriems metams po to, kai buvo pristatyta socialinio marketingo koncepcija.

Pasak Andreaseno ir kitų autorių (2005), yra tam tikri reiškiniai, kurie turi ịtakos ne pelno siekiančių organizacijų didèjančiam susidoméjimui tradicinėmis marketingo teorijomis, įrankiais bei technologijomis:

Vienas iš reiškinių, kuris lemia organizacijų susidomėjimą socialinio marketingo technologijomis, yra augantis pačių organizacijų noras savarankiškai kontroliuoti savo pelningumą bei finansinę nepriklausomybę. Toks noras yra visiškai suprantamas, nes ne pelno siekiančių organizacijų finansavimas iš valstybės biudžeto yra nepakankamas ir skiriamos piniginès lëšos netenkina organizacijos poreikių. Šios priežastys verčia ne pelno siekiančias organizacijas imtis papildomos veiklos ar projektų, kurie leidžia uždirbti pinigus ir padidina organizacijos biudžetą, leidžia išgyventi be papildomų dotacijų iš valstybės biudžeto. Dažniausiai organizacijos imasi vykdyti projektus, kurie yra susiję su sveikatos apsaugos programų igyvendinimu ir švietimo sistema;

Ne pelno siekiančios organizacijos dažnai marketingo technologijų ir įrankių panaudojimo idejų semiasi iš pelno siekiančių organizacijų veiklos, bendradarbiaudamos tarpusavyje ir igyvendindamos įvairiausius bendrus socialinius projektus. Tokie bendri pelno ir ne pelno siekiančių organizacijų susivienijimai rodo naujo požiūrio ị socialinị aktyvumą, kuris tampa pagrindiniu komponentu didžiųjų korporacijų verslo strategijose, atsiradimą. Didelès korporacijos naudoja spaudimą ir priverčia ne pelno siekiančias organizacijas keistis, nes pradeda finansuoti jas per bendrai vykdomus socialinius pro- 
jektus, o ne tiesiogiai skirdamos piniginių lèšų. Didžiosios korporacijos, dalyvaudamos bendroje veikloje su ne pelno siekiančiomis organizacijomis, dažniausiai tikisi, kad šios organizacijos sukaups nuosavą „žinių bagažą“, kuris ateityje galès būti panaudojamas socialiniam marketingui efektyvinti ir įtakai didinti, o pačios korporacijos dažniausiai tampa pagrindiniais žinių, susijusių su marketingo technologijomis, teikejjais ne pelno siekiančioms organizacijoms.

Trečiasis reiškinys - spaudimas ne pelno siekiančių organizacijų sektoriui, susijęs su marketingo technologijų, kurios buvo sėkmingai panaudojamos privačiame sektoriuje, perkèlimu i ne pelno siekiančio sektoriaus organizacijų veiklą. Šio spaudimo ištakos iš dalies yra susijusios su tradicinès filantropijos reiškinio kitimu ir naujosios „rizikos filantropijos" atsiradimu. Filantropija, kurios esmė buvo nesavanaudiška parama, pradèjo transformuotis ị naujają filantropiją, kurios esmè slypi investicijose į ne pelno organizacijas ir jų vykdomas veiklas, t. y. investicijos ị socialinius projektus, kurie ateityje taptų naudingi ne tik projektus vykdančiai ne pelno siekiančiai įstaigai, bet ir „rizikos filantropui“.

Kai kurios ne pelno siekiančios organizacijos tapo panašios ị dideles ir galingas korporacijas, kurios gali skirti lèšų savireklamai ir mokèti nemažus atlyginimus marketingo specialistams. Šios milžiniškos organizacijos yra labai modernios ir jos naudojasi tradicinio marketingo priemonėmis ne tik ịprastiems procesams (reklamai, investitoriams pritraukti), bet ir deklaruojamiems socialiniams tikslams pasiekti (Andreasen et al., 2005).

Kaip matome, marketingo technologijos transformavosi ir iš tradicinių verslo organizacijų perejjo ị visiškai joms priešingas - ne pelno siekiančias įstaigas. Jei net tokia, atrodo, visiškai neịmanoma, transformacija gali sèkmingai vykti šiuolaikiniame pasaulyje, tai kodèl gi nepanaudojus socialinio marketingo technologijų elektroninès valdžios projektams viešinti bei jų sẻkmingam ịgyvendinimui užtikrinti?

Kad tiksliai galètume suprasti, kaip turi veikti socialinis marketingas, reikia išsiaiškinti, kokios yra socialinio marketingo pagrindinès idejos, taip pat skirtumai tarp socialinių idèjų viešinimo ir tradicinių rinkų. Būtent skirtumai tarp socialinès ir tradicinès rinkodaros technologijų iš esmès paaiškina socialinio marketingo taikymo galimybes ir technologijas.

Pagrindinė problema, vykdant elektroninès valdžios projektus, yra tai, kad projektų vykdytojai susiduria ne su techniniais sunkumais, o tai, kad patys projektai yra prastai viešinami, mažai pristatomi plačiajai visuomenei bei nepakankamai reklamuojami. Tai ìvyksta dẻl to, kad ị projekto planavimo ir įgyvendinimo procesą dažniausiai neįtraukiami marketingo specialistai. Dèl nepakankamo socialinio marketingo technologiju panaudojimo projekto vykdymo metu nukenčia pats projekto žinomumas visuomenejje, o tai dažnai lemia neigiamą visuomenès, o kartais ir politinès valdžios nuomonę apie vykdomus projektus. 


\section{Socialinio marketingo kampanijos modelio konstravimas elektroninių viešųjų paslaugų projektų viešinimui}

Norint produktą ar paslaugą ịdiegti ị rinką ir sẻkmingai išlaikyti šị produktą rinkoje, būtina sukurti sèkmingą rinkodaros kampaniją. Kiekviena rinkodaros kampanija privalo turèti konkrečius tikslus, kurių pasiekimas reiškia, kad kampanija buvo sẻkminga ir produkto ar paslaugos tolesnis ,gyvenimas“ rinkoje taip pat bus sėkmingas ir ilgalaikis.

Taigi, žinant, kad rinkodaros kampanija yra būtina tradicinio marketingo pasaulyje, visiškai logiška manyti, kad socialinio marketingo kampanijos procesas taip pat privalo turèti tam tikrus apibrezžtus elementus.

Pasak MacFadyeno (1999) ir kitų mokslininkų, socialinio marketingo procesas yra sudarytas iš trijų pagrindinių elementų: vartotojų orientavimas, savanoriškojo keitimosi skatinimas ir ilgalaikis planavimas:

- vartotojų orientavimas (nukreipimas), pasak Kotlerio ir kitų autorių (1996), yra pagrindinis elementas bet kokio marketingo procese, kuris turi būti atskiriamas nuo produkto arba pardavimo. Socialinis marketingas iš esmès yra sudarytas taip: jo pagrindinè ideja - vartotojas yra laikomas pagrindiniu marketingo proceso dalyviu ir privalo aktyviai dalyvauti socialinio marketingo procese. Socialinio marketingo specialistu pagrindinis tikslas yra sukurti pasitikejimu pagrịstus, draugiškus ir glaudžius santykius tarp vartotojo ir socialinio projekto iggyvendinimo komandos tam, kad projekto vykdymo metu būtų galima gauti kuo daugiau informacijos ir žinių, kurios padètų sẻkmingai atlikti projekto igyvendinimo procesą. Trumpai tariant, vartotojų orientavimas yra procesas, kurio metu socialinio marketingo specialistas privalo suprasti visuomenès lūkesčius ir sugebèti pritaikyti projektą šiems lūkesčiams patenkinti;

- pasak Kotlerio ir Zaltmano (1971), socialinis marketingas yra grindžiamas ne tik vartotojo orientavimo filosofija, bet ir savanoriško keitimosi principu. Šie autoriai pažymejjo, kad „marketingo procesas neatsiranda ir nevyksta tol, kol nėra dviejų ir daugiau suinteresuotų pusių, kurios sugeba komunikuoti bei skleisti žinias, taip pat disponuoja šiomis žiniomis“. Tradiciniame marketinge keitimasis yra apibrěžiamas kaip apsikeitimas ištekliais ar vertybėmis tarp dviejų ar daugiau suinteresuotų šalių su tikslu gauti tam tikros naudos ateityje. Šalių ịsitraukimas ị mainų procesą dažniausiai yra sąlygotas būtinybès patenkinti savo poreikius ir troškimus (Houston and Gassenheimer, 1987). Lengviausiai apsikeitimo procesą paaiškinti kaip pinigu gavimą už suteiktas paslaugas ar pateiktas prekes, bet kartais jis gali turetti ir kitokias formas: balsas rinkimuose už kandidato pažadą sumažinti mokesčius arba asmeninis pasitenkinimas paaukojus pinigų nemokamai vakcinuoti Afganistano ar Kambodžos vaikus. Tradicinio marketingo esmé - pirkejjas ir pardavèjas, kurie yra ịtraukti ị mainų procesą, iš esmès sukuria rinkodaros atsiradimo poreikį. Kitais žodžiais tariant - ,rinkos atsiradimas reikalauja rinkodaros atsiradimo" (Adamet al., 1998). Socialinio marketingo procese keitimasis tampa savanoriškumo principu grịsta elgsena, kurios procesą turi skatinti socialinio marketingo kampanijos specialistai. Šiam tikslui marketingo specialistai turi pasiūlyti visuomenei kažką tokio, kas jai tikrai yra reikalinga. Norint identifikuoti visuomenès poreikị, reikia atlikti nemažai tyrimų ir išsiaiškinti visuomenei aktualias problemas, kurias marketingo 
kampanijos metu pateikti visuomenei, ir taip paskatinti savanorišką dalyvavimą socialinèse programose;

- socialinio marketingo, kaip ir tradicinio marketingo, procesas turi būti panašus ì ,ilgai veikiantị“" sudètingą mechanizmą ir turi būti grindžiamas gerai suplanuota ir argumentuota strategine kampanija. Socialinio marketingo planavimo procesas yra tapatus tradiciniam marketingui ir iš esmès jis prasideda ir baigiasi tyrimu, kurio tikslas išsiaiškinti, ar sékmingai buvo igyvendinta strategija. Situacijos analizè, išorinių ir vidinių faktorių ịtaka, taip pat projekto dalyviai ir naudotojai turi būti vienareikšmiškai identifikuoti ir ištirti. Šis procesas leis ateityje atlikti sèkmingą segmentavimo ir marketingo strategijos pritaikymo procesus. Socialinio marketingo strategijos elementai turi būti išbandyti su nedidelėmis tikslinėmis auditorijomis, îvertinti ir tik tuomet pateikti plačiajai visuomenei.

Kaip jau minèta anksčiau, socialinio marketingo planavimo procese mes privalome suprasti kelis esminius dalykus ir atsakyti ị kelis pagrindinius klausimus, kurių teisingas pozicionavimas bei teisingas atsakymas ị šiuos klausimus leis mums užsitikrinti sèkmingą projekto, skirto visuomenei, i̇vykdymą. Pavyzdžiui, panagrinėsime Lietuvoje bandytos įdiegti elektroninio balsavimo sistemos projektą ir pabandysime pateikti praktinius pavyzdžius, kurie gali padèti kuriant socialinio marketingo kampaniją šiam projektui. Elektroninio balsavimo sistemos įdiegimo projektas yra nagrinejjamas dèl to, kad tai projektas, kurị Lietuvoje bandoma ịgyvendinti jau šešetą metų ir kurio ịgyvendinimas labai reikalingas visuomenei, bet dèl tam tikrų priežasčiu (nepakankamas visuomenès informavimas, politinių jẻgų pasipriešinimas ir kt.) jis nėra sklandus. McKenzie-Mohras (2000) teigia, kad, norint sèkmingai įgyvendinti socialinio marketingo kampaniją, reiktų tokios socialinio marketingo kampanijos, kuri gali vienareikšmiškai identifikuoti ir nusakyti, kokiomis priemonėmis įmanoma pašalinti visas kliūtis, kurios gali vienaip ar kitaip trukdyti formuoti ar turèti ịtakos visuomenés ar jos suinteresuotų grupių elgesiui (McKenzie-Mohr, 2000).

Socialinio marketingo kampanijos sukūrimo procesą galima išskaidyti į 2 žingsnius: pirminis planavimas ir detalusis planavimas bei igyvendinimas. Pirminis planavimo procesas yra skirtas bendrajam vertinimui atlikti bei „pirminiam vaizdui“ suformuoti. Dalis duomenų, kurie bus renkami pirminio vertinimo metu, ateityje galès būti panaudojami detalaus planavimo ir igyvendinimo metu.

Norint atlikti pirminį socialinio marketingo kampanijos planavimą naujai diegiamos elektroninès viešosios paslaugos projekto vykdymo kontekste, reikia atlikti veiksmus, kurie pavaizduoti 1 pav. (pirminis planavimas):

1. Išsiaiškinti, kas bus šios viešosios paslaugos naudotojas ir kokie yra jo ateities lūkesčiai: Ko naudotojas tikisi iš naujos elektroninès paslaugos? Kokie veiksniai paskatintų naudotis nauja elektronine paslauga? Ar elektronine paslauga iš esmès neapsunkintụ paslaugos suteikimo galimybių? Ar paslaugos naudotojui nebus užkrauta papildomų materialinių išlaidų ir ar naudotojas privalès atlikti naujus administracinius veiksmus, siekdamas pradèti naudotis paslauga?

2. Atlikti pilotinius tyrimus, kurie parodys, kokia yra dabartinė visuomenès nuomoné apie planuojamą ịdiegti elektroninès valdžios projektą ir kas paskatintų visuomenę 
aktyviai dalyvauti projekto ịgyvendinimo veiksmuose. Būtina ištirti: ar igyvendinamas projektas yra palaikomas visuomenès? Ar jis teigiamai vertinamas suinteresuotų visuomenès grupių, nevyriausybinių organizacijų ir atskirų visuomenės individų? Išsiaiškinti, kokie pakeitimai ir projekto patobulinimai galètų paskatinti aktyvesnị visuomenės ir visuomeninių organizacijų dalyvavimą projekte? Kokius projekto vykdymo etapus, pvz.: projekto viešinimą ir populiarinimą, visuomenès nuomonès dẻl vykdomo projekto tyrimų organizavimą ir vykdymą, perduoti vykdyti suinteresuotoms nevyriausybinėms organizacijoms ar visuomenės grupėms? Kokias žinias, ịgūdžius bei socialines technologijas, naudojamas nevyriausybinèse organizacijose, pvz.: reklama socialiniuose tinkluose, virusinis marketingas, galima panaudoti elektroninės valdžios projektams viešinti?

3. Sukurti pirminị socialinio marketingo strateginio ịgyvendinimo planą, kuris: atsakytų, kokie faktoriai turi įtakos projekto ịgyvendinimo sėkmingumui? Kas turi ịgyvendinti elektroninès valdžios projektą ir kas bus pagrindinis elektroninès valdžios paslaugos naudotojas? Ar ši paslauga bus naudinga vartotojui ir ar ji tikrai yra jam būtina? Ar paslaugos sukūrimo ir palaikymo sąnaudos bus adekvatūs ir proporcingi šios paslaugos sukuriamai pridètinei vertei?

Galima teigti, kad kai tik bus atlikti anksčiau aprašyti žingsniai ir gauti atsakymai i visus klausimus, galima bus vienareikšmiškai nusakyti, ar elektroninès viešosios paslaugos įdiegimo projektas bus sėkmingas ir reikalingas visuomenei. Vèliau galima pereiti prie kito žingsnio, kuris yra ne mažiau svarbus nei pirminis kampanijos planavimas, - socialinio marketingo komplekso sukūrimas, kuris sudarytas iš šešių cikliškai besikartojančių etapų (žr. 1 pav.).

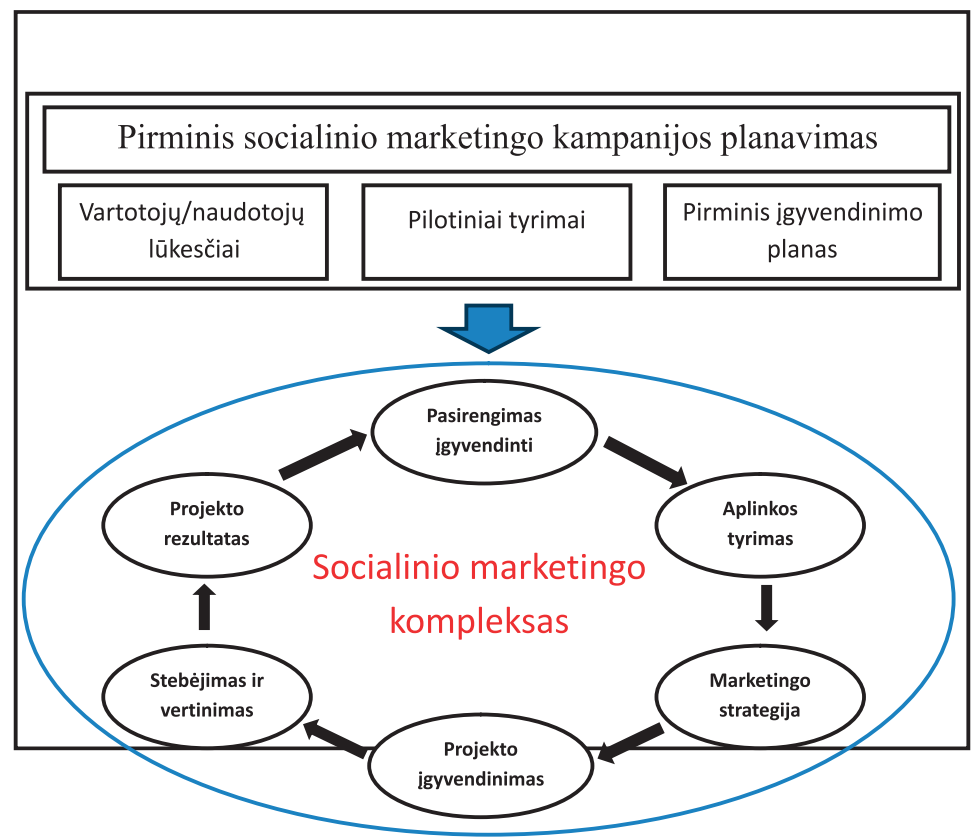

Šaltinis: sudaryta autorių

1 pav. Socialinio marketingo kampanijos planavimo modelis 
Būtina pasakyti, kad planuojama ir ịgyvendinama socialinio marketingo kampanija, o konkrečiau - socialinio marketingo kompleksas, nèra baigtinis procesas. Tai yra paprasčiausias ciklas, kuris kartojasi tol, kol pats projektas yra įgyvendinamas, o jo pabaiga yra siejama su socialinio projekto gyvavimo užbaigimu.

Planuojant ir vykdant socialinio marketingo kampaniją, pasak Perese ir kitų autorių (2005), būtina atsižvelgti ị šiuos esminius žingsnius:

- Tinkamai pasirengti igyvendinti socialinio marketingo kampaniją. Ši fazè yra pradinè ir pati svarbiausia socialinio marketingo fazè. Jos metu yra išgryninami ir susisteminami visi probleminiai klausimai, dèl kurių gali ịvykti nesklandumų projekto igyvendinimo metu, kurie gali turèti įtakos projekto iggyvendinimo eigai ir gyvybiškumui. Šiame etape būtina suformuoti tinkamą projekto ịgyvendinimo specialistų komandą, numatyti galimybes pasitelkti ekspertu , „iš šalies“, suformuoti aiškius ir pasiekiamus tikslus bei atlikti SSGG analizę, kurios pagrindinis tikslas - iš anksto numatyti projekto eigą, pasirengti galimoms grèsmèms ir sumažinti jų įtaką projekto eigai.

- Atlikti aplinkos tyrimus, kurie tiksliai nusakytų visuomenès (tikslinės auditorijos), kuriai yra skirtas socialinis projektas, bruožus: socialinis statusas, troškimai, elgsenos ypatumai, nuomonès bei elgesio kaitą lemiantys dalykai, lūkesčiai. Šiam žingsniui atlikti būtina pasitelkti specialistus, kurie gali atlikti visuomenès nuomonès tyrimą: sudaryti tikslų ir išsamų tyrimo planą, atlikti tyrimą, apdoroti gautus duomenis bei, gavus tyrimo rezultatus, tinkamai juos interpretuoti. Tyrimo rezultatai turès įtakos, vykdant kitą etapą ir parengiant marketingo strategiją.

- Marketingo strategijos parengimas turi apimti šiuos dalykus: tiksliai identifikuoti rinkos, i kurią orientuotas socialinis projektas, auditorijos segmentus ir parinkti šių auditorinių segmentų elgsenos poveikio priemones; aprašyti kiekvienos pasirinktos poveikio priemonès igyvendinimo procesą bei pasikeitimus, kurių tikimasi, veikiant tiriamas auditorijas; identifikuoti ir planuoti projekto biudžetą ir kitus resursus, būtinus projektui iggyvendinti.

- Atlikti socialinio marketingo kompanijos igyvendinimą: numatyti projekto populiarinimo veiksmus, informuoti tikslines grupes apie projekto igyvendinimo eigą, pritraukiant suinteresuotas nevyriausybines organizacijas ir visuomenès grupes. Projektui populiarinti pasitelkti netradicines socialines technologijas (socialinius tinklus, forumus ir kt.) bei viešojo informavimo priemones, t. y. vykdyti prieš tai buvusiame etape sudarytą marketingo strategijos ịgyvendinimą.

- Kitas etapas - stebèti ir ịvertinti vykdomos socialinio marketingo kampanijos eigą, pasirinktų tikslinių grupių reakciją bei jos pasikeitimą. Atlikti naujus tyrimus, kurie padès surinkti duomenų apie dabartinę visuomenès nuomonę apie vykdomą projektą, šiuos duomenis susisteminti bei atlikti tolesnę gautų duomenų analizę;

- Pasiekus paskutinị etapą - projekto vertinimą - galima bus vienareikšmiškai atsakyti, ar socialinio marketingo kampanija, sumanyta ir ịgyvendinta šiek tiek anksčiau, iš esmès buvo sèkminga ir ar planuojami rezultatai buvo pasiekti. Jei rezultatu pasiekti nepavyko, išsiaiškinti, kokie faktoriai lèmé šias nesékmes. Šis etapas gali būti laikomas paskutiniu socialinio marketingo proceso ịgyvendinimo etapu (sąlyginis socialinio marketingo proceso užbaigimas), jei buvo pasiekti visi tikslai, kuriuos kampanijos sumanytojai 
buvo išsikèlę pirmojo etapo metu. Jei visi tikslai buvo pasiekti, tai socialinio marketingo kampanija gali būti laikinai pristabdoma, bet privaloma numatyti projekto atnaujinimo datas, būsimų techninių ir finansinių poreikių prognozes, suinteresuotų asmenų galimus būsimus lūkesčius bei troškimus. Jei visų tikslų pasiekti nepavyko, tai viso ciklo vykdymas turi būti nedelsiant pradètas iš naujo, atsižvelgiant ị turimus projekto rezultatus ir atitinkamai koreguojant visus etapus.

Galima sakyti, kad, atlikus visus anksčiau ịvardytus veiksmus, socialinio marketingo procesas visuomet bus sėkmingas ir atneš apčiuopiamus rezultatus socialinio marketingo kampanijos sumanytojams bei vykdytojams. Naujai igyvendinami elektroninès valdžios projektai bus daug patrauklesni visuomenei, todèl sulauks papildomo visuomenès dèmesio. Visuomenès dėmesys ir socialinio marketingo veiksmų derinimas laiku leis naujiems ir jau igyvendintiems elektroninès valdžios projektams sẻkmingai išpopuliarėti tarp elektroninių paslaugų vartotojų.

Projektų valdymas viešajame sektoriuje yra tapatus kitų projektų valdymui ir savyje apima penkis globalius žingsnius: projekto inicijavimą, projekto planavimą, projekto vykdymą, projekto vykdymo kontrolę ir projekto užbaigimą (Project Management Institute, 2000). Visų šių žingsnių tarpusavio sąveika priklauso nuo to, koks yra prieš tai esančio žingsnio rezultatas.

Galima teigti, kad, nors projektų valdymo procesas yra tapatus viešojo ir privataus sektoriaus projektams, socialinio marketingo procesas iš esmès yra būtinas ir neatsiejamas viešojo sektoriaus (e. valdžios) projektams valdyti. Toliau pateikiamame paveiksle pavaizduota „e. valdžios projekto vykdymo“ stadija negali prasidèti be socialinio marketingo, kuris šiuolaikinėje visuomenëje tampa viena iš viešojo sektoriaus projektų valdymo proceso sudėtinių dalių, be kurios negalima įsivaizduoti nė vieno projekto, kuris yra vykdomas viešajame sektoriuje ir yra siejamas su visuomenei ar jos daliai teikiamomis paslaugomis arba visuomenès ịtraukimu ị viešojo sektoriaus veiklos procesus (žr. 2 pav.).

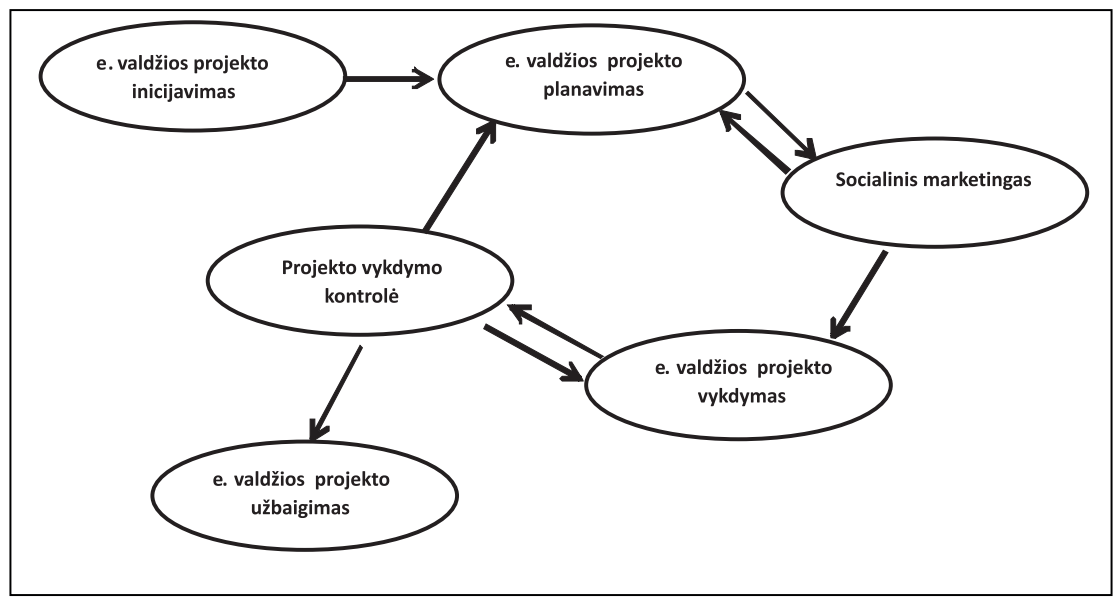

Šaltinis: sudaryta autorių

2 pav. Viešojo sektoriaus (E.valdžios) projektų valdymas (schema) 
Socialinio marketingo priemonių panaudojimas Lietuvoje ịgyvendinamų elektroninès valdžios projektų valdyme gali labai padidinti šių projektų sėkmingumą. Kaip pavyzdys gali būti nagrinejjamas Lietuvos elektroninio balsavimo sistemos sukūrimo projektas, kuris taip pat gali būti sèkmingai igyvendintas, pasitelkus socialinio marketingo priemones projekto vykdymo metu ir populiarinant elektroninių balsavimų sistemą visuomeneje. Šio straipsnio autorių nuomone, elektroninio balsavimo projektui igyvendinti ir viešinti nenaudojamos jokios socialinio marketingo technologijos ir priemonès, o tai sąlygoja, kad tam tikri visuomenès sluoksniai prieštarauja šios sistemos atsiradimui Lietuvoje. Didesnis viešumas ir socialinis marketingas iš esmès gali pakeisti susiklosčiusią situaciją ir pašalinti kliūtis, kurios trukdo sukurti elektroninio balsavimo sistemą.

\section{Išvados}

1. Socialinis marketingas yra tradicinio marketingo atšaka, kurioje yra susipynusios ivvairiausios mokslo šakos bei teorijos. Šis junginys paaiškina ir padeda suprasti, kaip galima daryti įtaką visuomenei ar atskiroms suinteresuotoms visuomenès grupèms bei kokiu būdu pritaikyti tradicinès rinkodaros priemones ir technologijas socialiniams tikslams pasiekti.

2. Socialinis marketingas nuo savo atsiradimo iki dabartinio momento patyrè nemažai transformacijų ir pakitimų. Šiuolaikinèje visuomeneje jis yra tapęs pagrindiniu įrankiu, kuris naudojamas kaip visuomenès pasirinkimo valdymo ir elgsenos kaitos priemonè, o socialinio marketingo proceso integravimas ị viešojo sektoriaus vykdomų projektų valdymo procesą gali labai padidinti ir garantuoti tokių projektų vykdymo sèkmingumą.

3. Sèkmingas socialinio marketingo proceso taikymas viešosioms paslaugoms populiarinti ir elektroninès valdžios projektų viešinimo kampanijų parengimas nėra lengvas, trumpalaikis ir baigtinis. Tai yra sunkus ir daug laiko bei pastangu reikalaujantis procesas, kurio tikslus, suplanuotas ir apgalvotas vykdymas atneštų teigiamų rezultatų bei padètų marketingo kampanijos rengimo specialistams įtraukti ị projekto vystymą ir dalyvavimą visas suinteresuotas visuomenės grupes, tuo pačiu metu lemdamas šių grupių elgseną bei teigiamą projekto vertinimą visuomenèje.

Gerai suplanuota socialinio marketingo kampanija ir siūlomas modelis teigiamai veiktų elektroninès valdžios paslaugų projektų priimtinumą visuomenèje bei padètų sékmingai įvertinti ir integruoti visuomenès lūkesčius, diegiant elektroninès valdžios projektus.

Socialinio marketingo procesas yra daugiapakopis ir sudètingas, bet atitinkamas pasirengimas šiam procesui ir tinkamo modelio taikymas visų marketingo strategijoje numatytų tikslų ịgyvendinimui teigiamai veiktų elektroninès valdžios paslaugų projektų vystymą ir jų viešinimą. 


\section{Literatūra}

Adam, S.; Armstrong, G.; Brown, L.; Kotler, P. 1998. Marketing, 4th Edition, Prentice Hall.

Alves, H. 2012. The Who, Where, and When of Social Marketing, Journal of Nonprofit \& Public Sector Marketing, 22 (4): 288-311.

Andreasen, A. 1993. A social marketing research agenda for consumer behavior researchers, Vol. 20, ed. Leigh McAllister and Michael Rothschild, Provo, UT: Association for Consumer Research, p. 1-5.

Andreasen, A. 1995. Marketing social change: changing behaviour to promote health, social, development and the environment. JosseyBass Publications, San Francisco, CA.

Andreasen, A.; Goodstein, R.; Wilson, J. 2005. Transferring ,, marketing knowledge“ to the non-profit sector, California Management Review, 47(4): 46-67.

Aras, R. 2011. Social marketing in healthcare. Australasian Medical Journal, 4(8): 418-424.

Bell, S., J.; Glenane-Antoniadis, A.; Menguc B.; Whitwell, G. 203. Extending the vision of social marketing through social capital theory: marketing in the context of intricate exchange and market failure. Marketing Theory, 3(3): 323-343.

Gassenheimer, J.; Houston, F. 1987. Marketing and exchange. Journal of Marketing, 51: 3-18.

Kotler, P., and Levy, S. J. 1969. Broadening the Concept of Marketing, Journal of Marketing, 33, 1: 10-15.
Kotler, P.; Zaltman, G. 1971. Social Marketing: An Approach to Planned Social Change. The Journal of Marketing, 35, No. 3: 3-12.

Kotler, P.; Armstrong, G.; Saunders, J.; Wong, V. 1999. Principles of Marketing, Second European Edition, England: Prentice Hall Europe.

Kotler, P.; Roberto, N.; Lee, N. 2002. Social marketing, improving the quality of life. Sage Publications.

MacFadyen, L.; Stead, M.; Hastings, G. 1999. Social marketing: a synopsis by the Institute for Social Marketing, University of Stirling Press, Scotland.

McKenzie-Mohr, D. 2001. Promoting Sustainable Behavior: An Introduction to Community-Based Social Marketing, Journal of Social Issues, 56: 543-554.

Perese, L.; Bellringer, M.; Abbott, M. 2005. Literature review to inform social marketing objectives and approaches, and behaviour change indicators, to prevent and minimise gambling harm. Wellington: Health Sponsorship Council.

Project management institute. 2008. A Guide to the Project Management Body of Knowledge, 4th Ed.

Wiebe, G. D. 1951. Merchandising commodities and citizenship on television, Public opinion quarterly, 15 (winter), p. 679-691. 


\title{
APPLICATION POSSIBILITIES OF SOCIAL MARKETING TECHNOLOGIES FOR PUBLICITY OF ELECTRONIC GOVERNMENT SERVICES
}

\author{
Tadas Limba \\ Mykolas Romeris University, Lithuania, tlimba@mruni.eu \\ Konstantin Agafonov \\ Mykolas Romeris University, Lithuania,ka1979@gmail.com
}

Summary. Nowadays e-government projects and projects in the public sector are changing the consistency and reality of our daily life and will need to be managed by project managers, who uge modern marketing tools and technologies. Social marketing is one of the modern marketing tools and, probably, it is the best tool to provide marketing in public sector project management, It has been changing in different ways since the founding of social marketing: the aim of social marketing, the technologies for using $i$; but nowadays it's hard to imagine public sector projects and, especially, egovernment projects, without using social marketing technologies. The usage of social marketing technologies can improve public sector project management and make the project more attractive to society or some part of it.

This scientific paper represents social marketing transformation, the way in which social marketing needs to be used in the public sector project management process and analyses the phases of social marketing. It also gives some practical advics for public sector organizations $o$, how to implement social marketing in the e-government project deployment process.

Keywords: social marketing, e-government, public sector project management, social marketing for e-government, e-government project management, e-government services. 